\title{
Ancient World of the Poet and Performance in Translations by Ants Oras
}

\author{
Janika Päll*
}

\begin{abstract}
This paper studies the means by which Ants Oras, scholar and professor of English and world literature, literary critic and translator, recreates the poetic space of ancient Greek hymns in his translations. The paper analyses his use of deictics (local, personal and temporal) in his translations of three Homeric Hymns: the 1st part of Hymn No. 3, to Delian Apollo, the Hymn No. 19, to Pan, and especially Hymn No 5 to Aphrodite. The special focus is on the initial and final parts of the hymns, where the Greek text reflects performance context, whereas Oras presents the poems in a more general, hymnal setting, leaving out the references which reveal the function of these hymns as epic prooemium.

The analysis of the deictics within the Hymn to Aphrodite reveals that Oras does not adhere strictly to the third person viewpoint of the narrator (as opposed to first person in direct speeches of the characters), but enlivens his narration by frequent deictics which refer to narrator's viewpoint, the poet's 'I', or 'here' and 'now'. This can only be occasionally explained with metrical reasons (preference to use monosyllabic deictics). This pattern of enlivening is in accordance to other practices, used by Oras in these translations: frequent personification of impersonalia (flight, mind) and multiplication of actors (objects of action becoming subjects, passive constructions turned active, and so on).
\end{abstract}

Keywords: Ants Oras, translation, Ancient Greek poetry, Homeric Hymns, Sappho

\section{Introduction}

This paper studies the means by which Ants Oras in his translations recreates the poetic space of the performance of ancient Greek hymns, paying special attention to his use of deictics in the translation of the Homeric Hymn (No. 5) to Aphrodite (Oras 1976).

Ants Oras has been important both for Estonian literary culture and the study of English literature world-wide. One of his biggest achievements was his translations of Virgil (Lange 2004, Lange 2007, Aunin, Lange eds. 2008).

\footnotetext{
* Author’s address: Janika Päll, University of Tartu Library, W. Struve 1, Tartu 50091, Estonia, email: janika.pall@ut.ee.
} 
As a literary critic Oras had been deeply interested in prosody, which finds a parallel in his essays of recreating the music of Virgilian hexameters. ${ }^{1}$ His translations of Virgil have been studied by a number of scholars. ${ }^{2}$ In the afterword to the reprint of Oras's translations of Virgil, Jaan Unt presents a short sketch of Estonian Virgiliana and also mentions his translation of the Homeric Hymn to Aphrodite. ${ }^{3}$ Although seemingly out of the more English- or Latinoriented focus of Oras, this translation is an appendix to his Virgiliana, as it tells the love-story of Venus and Anchises, which leads to the birth of the hero of the Aeneid. ${ }^{4}$ Belonging to the genre of epic prooemium (Kirk 1989: 69) ${ }^{5}$ and having common features with both the epic and lyric hymns, ${ }^{6}$ the hymn to Aphrodite offers excellent material for comparing the approaches of Oras in translations of works belonging to different genres.

I have followed the hypothesis that although deictic words have an extremely important role in the creation of poetic space, Oras translates them mostly intuitively, focusing on their sound and rhythm and not their referential or deictic functions. ${ }^{7}$ This implies that although the translator may be well aware of certain grammatical or lexical features (for example of different grades of deixis) in his source and target languages ${ }^{8}$ such distinctions do not always appear in the translations. In case of deixis the possible result is that differ-

1 See Oras 1962, his prefaces to the translations of the Bucolics and Aeneid (in Vergilius 1992) and the letters where he tells: "The result is a new kind of music resembling in a way the Latin language and Virgil - the Virgil of nostalgias" (Oras in Olesk ed. 1997: 171, translation in Lange 2007: 34).

2 Mägiste 1976, Unt 1992, Lange 2004: 377-394, Lotman 2012: 141-142.

3 For the complete list of works of ancient authors translated by Oras, see EAB 2014, cf. Lange 2007: 42-47.

4 In his youth Oras had presented verses $57-58$ of this hymn as an illustration (inter alia) to his claim that Shelley is much more 'graphic' in his descriptions of love scenes than the Greeks (1938: 35-37).

5 On their genre as an autonomous type of hexameter epic, see Clay 2011.

6 See Gerber 1997: 1-2, 6-8 for the role of 'I' - correspondingly on the foreground or background - as the major distinction between lyric and epic poetry.

7 Vincent Leitsch (2008: 23) characterises Oras the critic as disinterested in imagery, rhetoric and textual unity, but the use of narratological devices and deixis could be easily added to this list.

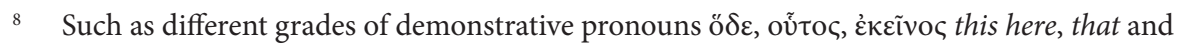
that (the more remote) in ancient Greek; the distinction between direct deixis, deixis am Phantasma and anaphora (Bühler 1990: 93-95, Latacz 1994: 313-321, and Felson ed. 2004). For the deictics in Estonian, see Pajusalu 1999. 
ent types of deictic words (personal/demonstrative, local, temporal) become mutually interchangeable, especially when the perspective of narration and the deictic centre (singer/narrator, character) remain unchanged. This means, for example, that the 'here' in the source text can become 'now' in translation, 'I' can be translated with 'here' etc. But the perspective itself and the deictic centre can be shifted as well, either completely or partially; for example direct speech can be replaced with indirect speech, active voice can become passive and the grammatical subject can become the object in the sentence. ${ }^{9}$

Oras has discussed the role of several monosyllabic deictics (for example nü̈̈d, siis trans. 'now', 'then') in translation from the aspect of prosody, examining their stressed or unstressed position in the sentence and the possibilities of using them as so-called anceps syllables (used either for long or short syllables) in hexameter (Vergilius 1992: 59). Verse translation, especially quantitative translation into stress languages, has very compelling constraints, which must be taken into account: a choice of one word over another can result from a need to fill the available space in a verse. ${ }^{10}$ However, a closer reading can reveal other tendencies, preferences and choices than only those resulting from prosody. For this, I begin with an analysis of typical epic prooemia: the beginnings of Homer's and Virgil's epic poems, aiming to explain the background for Oras's recreation of the poetic space in his translations of Homeric hymns.

\section{Homeric hymns as epic prooemia between lyric and epic poetry}

The world of ancient epic poetry with its boundaries in time and space is created by the words of a singer (or poet's 'I') through clearly distinguished and wellstudied means. ${ }^{11}$ The longer Homeric hymns use the same narrative patterns (background third person narrator with character speeches) as the epic. The study of these patterns, based on the distinction between diegesis and mimesis, telling and showing or narrator's text and character speech, has a long history,

\footnotetext{
9 A series of student papers dedicated to the study of deictics in Estonian translations of Hesiod, Plato, Virgil and Euripides (correspondingly Baikov 2008, Pille 2008, Tuulmets 2008; Kärtna 2010, Parvits 2010; Kiss 2010; Rootsma 2011) has revealed all these tendencies which occur alongside strictly accurate translations.
}

10 See Brunet ed. 2014 for the discussion from the perspective of translators of quantitative verse in different languages (Päll 2014 for Estonian).

11 See, for example, Latacz 1994, 2000, Gerber ed. 1997, de Jong 2004. 
beginning with Plato (Rep. III book, 392c-395) and Aristotle (Poet. 1448a and 1460a) and continuing with modern narratology (de Jong 2004: 5-8).

Greek epic song often begins with a prooemium, the singer's address to the Muse, whom he exhorts to tell the story. The passage from the prayer to the narration is usually unmarked (syntactically and/or lexically) and the singer, who in the beginning defined the boundaries of the performance space (his 'I' and the Muse) disappears into the background, leaving only traces. The beginnings of Homeric hymns are similar to the epic, but not the ends, where the singer reappears and closes the circle, re-establishing his presence by an address to the god (Nünlist 2004:35-36). This return to the prayer and poetic 'I' makes Homeric hymns close to the hymns in archaic lyric. ${ }^{12}$

The central narration in the hymns, which has been authorised by the address to the Muse, ${ }^{13}$ follows the joint perspective of the singer and the Muse, ${ }^{14}$ as a rule without references to the deictic centre and corresponding to the narrator's background role. ${ }^{15}$ In longer hymns, secondary perspectives appear in character speeches, which introduce their own deictic centres: thus the 'I-You' relationship of the singer and the divinity (the Muse, the god) can be replaced by the 'I-You' relationship of the characters.

My first goal is to see whether these quite strict rules of presentation of performance space in Greek epic prooemia are also observed in Estonian translations.

\section{The prooemia of ancient epic poems in Estonian translations}

The beginnings of Homer's poems establish the performance situation from verse one. In the Odyssey, the address to the Muse is accompanied by unstressed deictic $\mu \mathrm{ol}$ (me), referring to the singer, whereas in the Iliad the address is

\footnotetext{
12 See Fränkel 1955, Fowler 1987.

13 For the role of Muses as guardians of truth and memory, see Detienne 1990: 9-12.

14 Calame (1986 and 2005) studied Homeric hymns from the point of view of enunciation, extra-and intratextual relations. I prefer to speak of a joint perspective in places where he speaks of 'dédoublement' or projection of the role of the 'I' of the singer to the Muse (Calame 1986: 20-23 or $40-41)$.

15 The deictic centre can be also marked by the first person verb forms or, in the case of address, by the use of second person verb forms, imperative or vocative; see Dickey 2003 (for vocatives), de Jong 2004: 54-60, 13 for focalisation, and 2004: 180-188 for deixis in messenger speeches.
} 
presented without a deictic pronoun (although the use of vocative establishes the 'I-You' relationship). August Annist, ${ }^{16}$ the author of the first and only complete Estonian translations of both Homeric epics, has maintained this difference:

\begin{tabular}{|c|c|}
\hline Homer, Odyssey, v.1 & translations \\
\hline 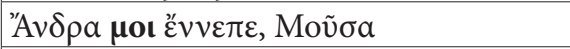 & Tell me, o Muse, of this hero \\
\hline $\begin{array}{l}\text { Annist: Jutusta mulle, oh Muusa, sest } \\
\text { sangarist }\end{array}$ & Tell me, o Muse, of this hero \\
\hline Bergmann: Meest mulle nimeta, muusa & Name me the man, oh Muse \\
\hline Öpik: Meest mulle nimeta, muus & Name me the man, oh Muse \\
\hline
\end{tabular}

Annist used the strong, longer form of the first person pronoun, thus slightly underlining the reference to the deictic centre. Other, earlier translators of the first song of Odyssey, Jaan Bergmann and Anna Öpik used the first person pronoun in a similar way. ${ }^{17}$

The beginning of the Iliad in Greek does not use the first person pronoun for an explicit reference to the deictic centre, and neither do most of its Estonian translators:

\begin{tabular}{|c|c|}
\hline Homer, Iliad, v.1 & translations \\
\hline 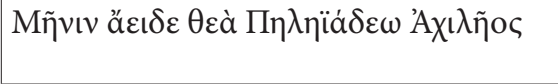 & $\begin{array}{l}\text { Sing, o Goddess, the anger of Peleides, } \\
\text { Achilleus }\end{array}$ \\
\hline $\begin{array}{l}\text { Annist: Laula nüüd, oh, jumalanna, } \\
\text { Peleides Achilleuse vimmast }\end{array}$ & $\begin{array}{l}\text { Sing now, o Goddess, the anger of } \\
\text { Peleides, Achilleus }\end{array}$ \\
\hline $\begin{array}{l}\text { Ridala: Laula, oh jumalatar Peeleidi } \\
\text { Achillese viha }\end{array}$ & $\begin{array}{l}\text { Sing, o Goddess, the wrath of Peleides } \\
\text { Achilleus }\end{array}$ \\
\hline $\begin{array}{l}\text { Lõo: Laul jumaltar sa vihast Peleuspoja } \\
\text { loo Akhileusi }\end{array}$ & $\begin{array}{l}\text { You, Goddess, compose a song about } \\
\text { the wrath of the son of Peleus, Achilleus. }\end{array}$ \\
\hline $\begin{array}{l}\text { Metslang: Kuuluta mulle, oh muusa, } \\
\text { Peleides-Achilleuse vaenu }\end{array}$ & $\begin{array}{l}\text { Announce me, oh Muse, the wrath of } \\
\text { Peleid Achilleus }\end{array}$ \\
\hline
\end{tabular}

However, Annist added a temporal deictic adverb nü̈̈d ('now'), underlining the performance time (present) and poetic context, which in Homer is marked

\footnotetext{
16 I refer to August Annist, who was the versifier. As Annist collaborated closely with his editor, Hellenist Karl Reitav, in newer bibliographies both have been named as authors of the translation (EAB 2014). All quotations from Homer and Homeric hymns are from the edition of Allen 1904, TLG version, translations, if not indicated otherwise, are my own.

17 For texts, see Eesti värss: http://www.ut.ee/verse/index.php?\&m=authors\&aid=2\&obj=poe ms\&apid=861 and Antiigiveeb, http://www.fl.ut.ee/et/519342.
} 
only by the address. ${ }^{18}$ Other translators of Iliad's beginning, Villem Ridala, Jaan Lõo and Linda Metslang have not changed the type of deictic. ${ }^{19}$ Lõo added the unstressed form of the second person pronoun, perhaps in order to fill a space of one short syllable in the hexameter, and Linda Metslang added first person pronoun mulle ('to me'). ${ }^{20}$ In Estonian, the transitive use of the verb meenutama, meelde tooma ('to remember') needs a complement which indicates to whom something is remembered.

When we compare Homeric beginnings to the opening verse of Virgil's Aeneid, we see that the focus on the poet's self-consciousness is stronger in the Roman epic, as well as its translation. Virgil does not abandon the traditional appeal to the Muse, which occurs slightly later, in verse 8 with a stressed pronoun mihi in the phrase-initial position: ${ }^{21}$

\begin{tabular}{|l|l|}
\hline v. 1: Arma virumque cano & The swords (I) sing and the man. \\
\hline Oras: Mõõku ma laulan ja meest & The swords I sing and the man. \\
\hline v. 8: Musa, mihi causas memora & Muse, remind me the reasons \\
\hline $\begin{array}{l}\text { Oras: Meelde, oo Muusa, mul põhjused } \\
\text { too }\end{array}$ & $\begin{array}{l}\text { Muse, bring to me into mind the rea- } \\
\text { sons }\end{array}$ \\
\hline Anvelt: Meenuta mulle, oh muusa & Remind me, Oh Muse.... \\
\hline
\end{tabular}

The pronoun mul ('for me') is present both in Oras's (who uses its weaker form) as Leo Anvelt's translation, ${ }^{22}$ who uses the longer, more stressed form. In verse 1 Oras uses the first person pronoun in the role of the subject (as usual in Estonian).

These examples demonstrate that in Estonian translations of Homeric and Virgilian epic prooemia, a tradition has been established to translate the deictics occurring in Greek or Latin text by corresponding Estonian deictic words (although occasionally with a slight increase or reduction of the deictic centre,

18 Nü̈̈d ('now') in Estonian is slightly ambivalent, as it can be also used as hortative particle, similarly to corresponding particles vvv and nunc in Greek and Latin.

19 For texts, see: Eesti värss, http://www.ut.ee/verse/index.php?\&m=authors\&aid=12\&obj=p oems\&apid=1188 and Eesti värss, http://www.ut.ee/verse/index.php?\&m=authors\&aid=9\&ob $\mathrm{j}=$ poems\&apid $=1382$.

20 For texts, see: Antiigiveeb, http://www.fl.ut.ee/et/524324.

21 Here and later the words inserted by translators are presented in round brackets, for example, personal pronouns in the role of subject, which are not needed (as the case ending indicates the person) in Greek and Latin.

22 In: Kaalep, Torpats eds. 1971: 296. 
connected to the singer), thereby recreating the spatio-temporal field of the performance. Now it is time to study the approach of Ants Oras in the case of independent epic prooemia, the Homeric hymns.

\section{The performance context in Oras's translations of Homeric hymns}

Homeric Hymn to Aphrodite begins and ends traditionally, with framing prayers. ${ }^{23}$ The singer asks the Muse for inspiration and then steps into the background, telling the love-story of his divine addressee, Aphrodite, with a mortal man, Anchises, and introducing their speeches occasionally.

The address to the Muse in verse 1 indicates the two participants of the performance situation (the singer and the Muse) as well as the story's main character and addressee, Aphrodite. The presence of the poet is stressed by the first person pronoun $\mu \mathrm{ol}$ ('me'). In his translation Oras omits the first person

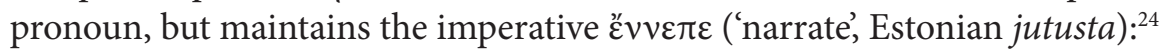

\begin{tabular}{|c|c|}
\hline 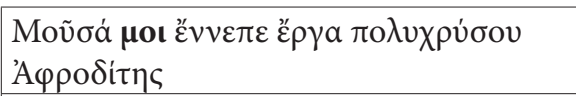 & $\begin{array}{l}\text { EW: Muse, tell me the deeds of golden } \\
\text { Aphrodite the Cyprian }\end{array}$ \\
\hline $\begin{array}{l}\text { Oras: Laulutar, jutusta lood Aphroditest } \\
\text { uldkiharkaunist }\end{array}$ & $\begin{array}{l}\text { Singer, tell the stories about Aphrodit } \\
\text { with beautiful golden locks }\end{array}$ \\
\hline
\end{tabular}

Through this omission Oras reduces the references to the deictic centre and performance situation, although the second person imperative and address still indicate it. This might be explained by prosodic constraints, ${ }^{25}$ but not the next omission, which occurs in the end of the hymn. In the end of the Greek text (verses 292-293) the performance situation is re-established by the singer's address to Aphrodite:

23 For circular structures see Fränkel 1955: 97, van Groningen 1958: 51-56, Nünlist 2004, compare Norden 1913.

24 Thus the imperative is left without a complement which it usually requires in Estonian. The translations of Hugh Evelyn-White (1914) are indicated with EW.

25 It might be difficult to find an appropriate translation in Estonian hexameters for the

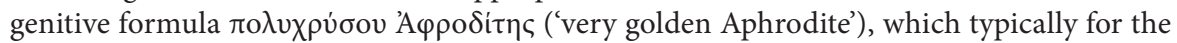
appositive epic style occurs in the end of the verse, whereas in Estonian, (genitive) complements need to precede the noun, not follow it. It would be easy (and smoother from the point of view of quantitative verse) to replace the second word jutusta $\left(-\_\cup\right)$, not quite fitting into the first foot) by Ütle mul $(-\cup \cup)^{\prime}$ ' ('tell me'), but the result would sound too prosaic. 


\begin{tabular}{|c|c|}
\hline 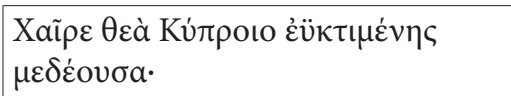 & $\begin{array}{l}\text { EW: Hail, goddess, queen of well-build- } \\
\text { ed Cyprus! }\end{array}$ \\
\hline 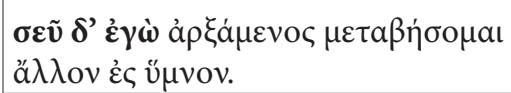 & $\begin{array}{l}\text { with you have I begun; now (I) will turn } \\
\text { (me) to another hymn }\end{array}$ \\
\hline
\end{tabular}

The address in verse 292 alone is sufficient as a reference to the performance situation, but in v. 293 it is followed by explicit auto-reference of the singer with two stressed deictics in phrase- and verse-initial positions: $\sigma \varepsilon \tilde{v} \delta^{\prime} \dot{\varepsilon} \gamma \omega \dot{\omega}$ ('with you I'). However, Oras finishes his translation before these two verses (in verse 211, corresponding to v. 291 in Greek) with the end of the speech of Aphrodite, foretelling the future. ${ }^{26}$

The relatively short Homeric hymn to Pan (Hymn No. 19) is similarly framed by the addresses to the divinities, establishing the performance situation. The first verse adhorts the Muse to tell the singer the story of Hermes:

\begin{tabular}{|c|c|}
\hline loṽ $\sigma \alpha$ & ames \\
\hline me. Jutucts Muuce mis toeb [ ]/l & $\begin{array}{l}\text { Tell, Muse, what does [...] the son of } \\
\text { Hermes }\end{array}$ \\
\hline
\end{tabular}

Oras again omits the first person pronoun which refers to the deictic centre and the performer (the deictic centre is indicated only through the use of the imperative). In the end of the hymn he follows the same pattern as in the case of the hymn to Aphrodite and leaves the final verses with the poet's autoreference (in verses 48-49 of the Greek text) untranslated:

26 Oras usually shortens and joins verses within a paragraph (see the table below) and even omits several passages (v. 48-52, 202-246 and 292-293). As a result the 293 verses of this hymn are reduced to 211 in his translation.

Table 1. Correspondence of verse numbers in shortened passages in the hymn to Aphrodite and its translation.

\begin{tabular}{|l|l|l|l|l|l|l|l|l|l|}
\hline "Homer" & Oras & "Homer" & Oras & "Homer" & Oras & "Homer" & Oras & "Homer" & Oras \\
\hline $25-32$ & $25-31$ & $60-64$ & $50-52$ & $113-125$ & $97-107$ & $176-179$ & $152-154$ & $256-258$ & $183-184$ \\
\hline $36-38$ & $35-36$ & $69-74$ & $58-62$ & $126-129$ & $108-110$ & $180-184$ & $155-158$ & $259-268$ & $185-191$ \\
\hline $\begin{array}{c}45-48, \\
53-55\end{array}$ & $43-47$ & $75-83$ & $63-69$ & $150-154$ & $130-133$ & $192-195$ & $166-168$ & $269-272$ & $192-194$ \\
\hline $56-59$ & $48-49$ & $95-99$ & $81-83$ & $157-166$ & $136-142$ & $249-254$ & $177-181$ & $273-275$ & $195-196$ \\
\hline & & & & & & & & $280-283$ & $201-203$ \\
\hline
\end{tabular}




\begin{tabular}{|c|c|}
\hline 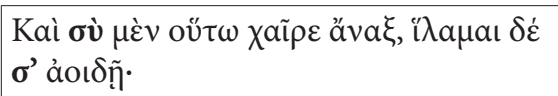 & $\begin{array}{l}\text { EW: And so hail to you, lord! I seek your } \\
\text { favour with a song. }\end{array}$ \\
\hline 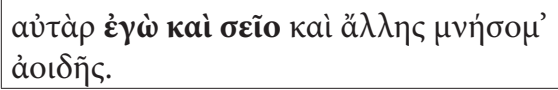 & $\begin{array}{l}\text { And now I will remember you and an- } \\
\text { other song also. }\end{array}$ \\
\hline
\end{tabular}

These two translations follow an identical pattern: Oras addresses the Muse, but subdues the reference to the singer's 'I' and omits the closure, where the poet addresses the god and promises to proceed to the next hymn. So it seems that Oras does not consider it important to present these hymns as epic prooemia. Moreover, his tendency to omit first person pronouns is contrary to the general practice of translating from ancient languages into Estonian where the number of personal pronouns (including first person) in target language is usually greater than in source language, because the grammatical subject normally needs to be expressed by a noun or pronoun. ${ }^{27}$

The example of his Hymn to Delian Apollo is different. It is the translation of the first part of Homeric Hymn No. 3, which is exceptional among Homeric hymns because of its two-fold structure ${ }^{28}$ and the mixture of second and third person narrations in the middle part (Nünlist 2004: 36, esp. 40-42). ${ }^{29}$ The hymn begins with a first person statement of the singer who promises to remember Apollo, thus taking the role of the guardian of memory onto himself:

\begin{tabular}{|c|c|}
\hline 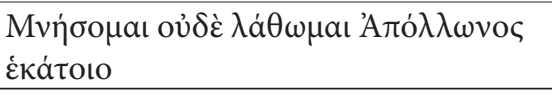 & $\begin{array}{l}\text { EW: (I) will remember and not be un- } \\
\text { mindful of Apollo who shoots afar }\end{array}$ \\
\hline $\begin{array}{l}\text { Oras: Meeles on, meelest ei eal kao } \\
\text { kaugelelaskja Apollon. }\end{array}$ & $\begin{array}{l}\text { Apollo, the far-shooting is remembered } \\
\text { and shall not be forgotten. }\end{array}$ \\
\hline $\begin{array}{l}\text { Murdvee: Meeles mul, vaikida ei Apol- } \\
\text { lonist saa }\end{array}$ & $\begin{array}{l}\text { (He is) in my memory, (I) cannot be } \\
\text { silent of Apollo }\end{array}$ \\
\hline
\end{tabular}

Two Greek first person verb forms in phrase- and verse-initial position firmly establish the performance situation, drawing attention to the singer in the focus, but at the same time also pointing to the future, away from the

\footnotetext{
27 Differently from ancient Greek and Latin, where the use of the third person personal pronoun is very rare and demonstrative pronouns are used, in Estonian the third person personal pronoun is usual, and demonstrative pronouns can only very rarely be used for referring to persons.

28 So-called Delian and Pythian hymns, for the arguments in favour of unity, see Clay 2006, Steinrück 1992.

29 The apostrophes can be connected to the divine, and third person narration to the human layer of the story, see Steinrück 1992: 255-256.
} 
temporal centre. ${ }^{30}$ In the beginning of his translation, Oras omits any references to singer's ' $\mathrm{I}$ '. He also changes the sentence so that that the god Apollo (the addressee and main character of the hymn), grammatical object in Greek sentence, becomes the grammatical subject in the translation. Apollo is thus clearly in focus, but presented outside the performance context. As a result of this change the transitive first person verb form 'remember' appears as a third person verb complement (Apollon on meeles [Apollo is remembered]), but without any first person pronoun, which would indicate the person who remembers (singer's ' $I$ '). This does not result from prosodic constraints: it would have been easy to insert the first person pronoun ('mul'), as was done by another translator, Mari Murdvee (Murdvee 2006: 71).

The end of this hymn (verses 545-546) includes a finishing formula with a reference to the performance situation (similar to the hymn to Pan), but it cannot be taken into account in the analysis, because Oras did not translate the second part of the hymn. However, the end of the first part of the poem includes another auto-referential passage, which occurs in Oras's translation as well.

After the narration about the birth of Apollo, the narrator describes the choir of Delian girls who sing in the honour of the god (v. 156-178). The singer addresses the choir in direct speech, referring to himself in first person plural, asking to remember him in the future and to answer the questions of wondering stranger, who will ask: Whom think ye, girls, is the sweetest singer that comes here, and in whom do you most delight? (v. 169-170, translation by Evelyn-White)

The short questions of stranger and the choir's answer are similarly presented in direct speech. The choir's answer to the singer's exhortation functions as a kind of sphragis, author's signature (Kirk 1989: 72), referring to the singer as a blind man from Chios, whose songs are supreme. Thus the narrator becomes a character in his own story (Steinrück 1992: 255) and the choir takes the role of the singer as praise-giver, but only briefly, as the singer takes his role back and promises to give in his turn the fame to the choir (see v. 173-178 below).

In the history of Greek literature this singer (and author) has been identified with Cynaithios from Chios, but the same passage has also supported the

30 It occurs often in the beginnings of lyric songs, where song-initial verbs (and especially the first person forms) establish the spatio-temporal field at once (Päll 2005: 335-338, for general background, Devine, Stephens 1994: 381, 456-460, Dik 1995: 12-13). 
legend about Homer as a blind singer. ${ }^{31}$ In this performance inside a performance the main deictic centre is for a moment shifted from the singer to the stranger (in v. 169-170) and then to the choir (in v. 172-173, both without explicit references to a new deictic centre) and the back to the singer, whereas the shift in time is indicated by future verb forms (in v. 174, 176):

\begin{tabular}{|c|c|}
\hline 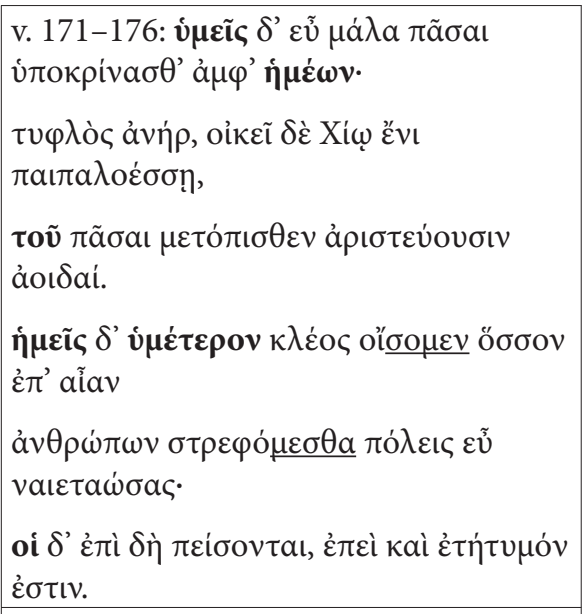 & $\begin{array}{l}\text { As for me }[=\text { us], }(\mathrm{I})[=\text { we }] \text { will carry } \\
\text { your renown as far as }(\mathrm{I})[=\text { we }] \text { roam } \\
\text { over the earth to the well-placed cities } \\
\text { of man, and they will believe also; for } \\
\text { indeed this thing is true. }\end{array}$ \\
\hline $\begin{array}{l}\text { Oras, v. 147: Teie siis kõik ühes koos siis } \\
\text { kostke ja vastake talle: }\end{array}$ & You all together answer and tell him: \\
\hline $\begin{array}{l}\text { "Üks pime mees elab kaljusel Chiose } \\
\text { saarel, }\end{array}$ & $\begin{array}{l}\text { "A blind man dwells in rocky island of } \\
\text { Chios: }\end{array}$ \\
\hline $\begin{array}{l}\text { kõikidest teitest ta laul jääb kauneimaks } \\
\text { iidigavesti." }\end{array}$ & $\begin{array}{l}\text { his songs about you all will be forever } \\
\text { supreme." }\end{array}$ \\
\hline $\begin{array}{l}\text { Siis teie kuulsuse viin maa viimsesse, } \\
\text { kaugesse äärde, }\end{array}$ & $\begin{array}{l}\text { Then (I) will carry your renown to the } \\
\text { far end of the earth, }\end{array}$ \\
\hline $\begin{array}{l}\text { kõikjale kannan, kus linnad on püstitet } \\
\text { kõrged ja kaunid, }\end{array}$ & $\begin{array}{l}\text { everywhere where high and beautiful } \\
\text { cities have been built, }\end{array}$ \\
\hline $\begin{array}{l}\text { kõikjal siis ustakse mind [=me], sest } \\
\text { see, mis ma ütlen, on õige. }\end{array}$ & $\begin{array}{l}\text { then I'll be believed everywhere, } \\
\text { because what I say is true. }\end{array}$ \\
\hline
\end{tabular}

The choir's answer is in the Greek text framed by the singer's autoreferences in the first person plural, which is uncharacteristic for Homeric hymns, but very

31 See Allen and Sykes 1904 ad v. 172 and v. 169 (quoting Hesiod's fr. 227). 
typical in Greek lyric hymns (which are performed by choirs); ${ }^{32}$ the deictic centre is expanded from ' $I$ ' to 'we'. In his translation of the singer's exhortation (v. 171 in Greek text), Oras uses the second person plural pronoun and imperative, but omits the explicit reference (the 'we') to the deictic centre and indicates the new addressee (the stranger) with the third person pronoun. He twice uses the adverb siis ('then'), referring to the future (Estonian does not have morphological future). In three verses following the choir's answer, Oras returns to the local deictic centre ('here') of the singer, but renders the choir's 'we' with the singular first person pronoun, clearly re-establishing the deictic centre of the singer in place and in person, but remaining in the future (indicated again by siis 'then').

The end of the first part of the Greek text includes the singer's shift to the initial, first person singular deictic centre without a direct address to the god; the singer himself is in the role of the guardian of memory and promises to sing about Apollo:

\begin{tabular}{|c|c|}
\hline 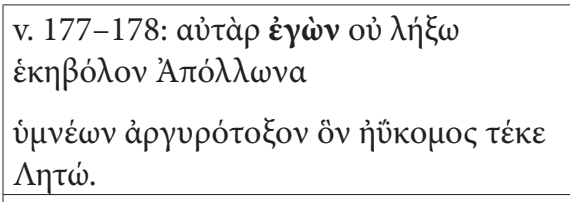 & $\begin{array}{l}\text { EW: And I will never cease to praise far- } \\
\text { shooting Apollo, } \\
\text { god of the silver bow, whom rich-haired } \\
\text { Leto bare. }\end{array}$ \\
\hline $\begin{array}{l}\text { Oras: Sind üha kiidan ma ent, hõbeam- } \\
\text { muga ambuv Apollon, } \\
\text { Sind, keda ilmale tõi kiharkaunis här- } \\
\text { randlik Leto! }\end{array}$ & $\begin{array}{l}\text { You I'll praise without ceasing, Apollo } \\
\text { who shoots with silver bow, } \\
\text { you, whom imperious Leto with fair } \\
\text { hair has brought into the world. }\end{array}$ \\
\hline
\end{tabular}

The stressed Greek personal pronoun 'I' in a strong, phrase-initial position is here translated with the unstressed ' $I$ ' in a weak position by Oras. But the reference to Apollo (which in Greek is in the third person, using his name and epithets and a relative clause) has been replaced in Estonian by a double apostrophe, addressing the god with two stressed second person pronouns in verse-initial positions (sind). Thus Oras changes the performance landscape where the singer is in the focus into another one, where the deictic centre of the singer becomes less important than his subject, the god, whom the poet addresses.

In his short postscript to the translation, Oras mentions that these final verses are the basis for the legend that Homer was a blind singer from the

32 For this fluctuation between 'I' in singular and the plural form, and the role of the choir in it, see Lefkowitz 1963, 1991: 9-11,57-71. The underlined autoreference between the two parts of the hymn is in accordance with its transitional character between the stages of narration or parts of poems (see Lefkowitz 1991: 55-56). For framing in Homer's epics see Bakker 1997: 86-122. 
island of Chios. He also refers to Homeric hymns as epic prooemia (prologues) to the performance of longer epic poems. "All of them address one or another god in a hymnal tone, mostly very shortly, but in some of them the instinct of the singer has not managed to maintain them in the frames of the lyric, but it blossoms into epic, sometimes indeed excellently" (Oras 1976: 34). These words suggest that Oras regarded Homeric hymns foremost as hymns, which by register are closer to lyric poetry. While omitting the formulaic verses which refer to the performance of epic songs, the blind-man-verses were probably kept by him because of the legend which is famous in literary history.

If we suppose that Oras wanted to recreate the lyric, hymnal character of Homeric hymns, a comparison with his translations of Sappho's lyric poems is appropriate.

\section{Oras the translator of Sappho}

Sappho's Ode 1 To Aphrodite is a hymn framed by the singer-poet's prayers to the goddess whereas the central part describes Aphrodite's epiphany. In his translation Oras has retained the intimate and personal character of the ode. He included all references to the deictic centre with first person personal pronouns, which occur in the Greek text, and even added some. ${ }^{33}$ Oras also augmented the occurrences of the second person pronoun 'you': (10 times, in Greek 5 or 6). ${ }^{34}$ The majority of the second person pronouns in his translation (6) occur in Aphrodite's words, spoken during her epiphany and addressing the singer (Sappho), especially in verses 21-24 (sixth stanza).

This much discussed stanza offers two important ambiguities: ${ }^{35}$ firstly, the speaker and the time are not clear, as the references to the deictic centre are absent and the stanza itself is in a transitional position, occurring at the end of the narration about the epiphany of the goddess in the past and her address to Sappho just before the final, seventh stanza, where Sappho the poet returns

33 Correspondingly 5 occurrences in Greek, v. 3, v. 6, v. 17, v. 25, 26, and 7 in Estonian: v. 3, 6, 13, 15, 25 (twice), 28. Once, in v. 16 Oras slipped from direct speech into indirect for a moment and used the third person pronoun in Aphrodite's words to Sappho (Miks teda hüüdsin? ['Why did I call her?']) in place of sg. sind ('you'), probably because of metrical reasons (needing to use two short syllables in the adonion.)

34 Depending from the readings of the text in verse 19 (бáv or Fáv), see Voigt 1971 ad loc.

35 For ambiguity intertwined with autoreferentiality, see Calame 2004 (especially p. 415-416, 420-423). 
from narration to prayer and speaks again as her poetic self in the first person. ${ }^{36}$ Secondly, it is not clear who are the desirer and desired in this stanza which speaks of love and rejection.

The words can belong either to Aphrodite or Sappho and be understood either as a timeless example concerning two lovers (one of them is a reluctant girl) or as Sappho and the reluctant girl she desires: ${ }^{37}$

\begin{tabular}{|c|c|}
\hline v. 21-24: kaì үà & $\begin{array}{l}\text { If (she) runs away, soon (she) shall pur- } \\
\text { sue; }\end{array}$ \\
\hline 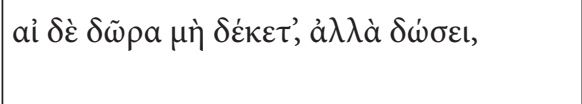 & $\begin{array}{l}\text { if (she) does not accept gifts, why, (she) } \\
\text { shall give (them) instead; }\end{array}$ \\
\hline 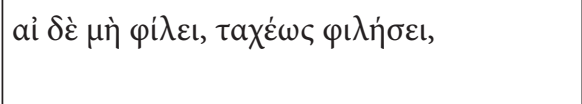 & $\begin{array}{l}\text { and if (she) does not love, soon (she) } \\
\text { shall love }\end{array}$ \\
\hline 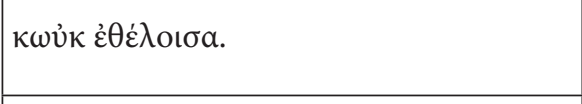 & $\begin{array}{l}\text { even against (her) will. (trans. David A. } \\
\text { Campbell) }\end{array}$ \\
\hline $\begin{array}{l}\text { Oras: Väldib sind, küll pea on sul järjest } \\
\text { kannul; }\end{array}$ & $\begin{array}{l}\text { If (she) avoids you, soon (she shall) be } \\
\text { following you; }\end{array}$ \\
\hline tõrjub kinke sult - ise peatselt pakub, & $\begin{array}{l}\text { if (she) sends back your gifts, soon (she } \\
\text { will) offer (them) herself; }\end{array}$ \\
\hline on su vastu külm - süda pea tal süttib, & $\begin{array}{l}\text { if (she) is cold toward you - soon her } \\
\text { heart will be in flames, }\end{array}$ \\
\hline tahtku või m & be (she) wanting or not. \\
\hline
\end{tabular}

Campbell has preserved this ambiguity in his translation..$^{38}$ Oras, however, interprets the rejected lover as Sappho, who is addressed by Aphrodite with a fourfold repetition of the personal pronoun 'you' in direct speech. Although Oras's translation remains ambiguous from the point of view of gender (which can be expressed in Estonian only with lexical means), he mentions Sappho's

36 For the analysis of narrative situation, see Steinrück 1992: 280-287, for transition character, see Päll 2007: 44, 48. Tzamali (1996: 81) interpretes the addressee as Sappho, speaking of "brachylogische Ersparung von $\sigma \varepsilon ́$ as selbstverständlich", her discussion of syntax in this stanza follows this interpretation (Tzamali 1996: 79-84).

37 Translation in Campbell 1994: 53-55.

38 Adding third person pronouns, which are needed in English; thus the result is seven pronouns in translation, where Greek has none, although at least one of them is absolutely necessary to express the gender (feminine) of the reluctant lover (expressed by the feminine participle in the text of Voigt's edition, v. 24). 
passion for some of the girls in her group in his afterword to the translation, thus giving guidance for the interpretation of the love scene. ${ }^{39}$

The same accumulation of personal pronouns occurs in his translation of Sappho's fragment 31, where five first person pronouns occur in Greek and six in Estonian, and only two second person pronouns in Greek and six in Estonian. ${ }^{40}$ Nor does Oras avoid the references to the first person in his translation of Catullus' version of the same poem (Carmen 51). ${ }^{41}$ The same claim can be made about his other translations of Catullus or Horace.

So it appears that in the case of personal lyric poetry Oras does not avoid references to the deictic centre. Corresponding to the manner of deixis am Phantasma, as-if presence of the speaker and pointing at the listeners, he even adds such references and creates his poetic space with the help of abundant deictics (especially in addresses).

Until now we have not seen how Oras uses the deictics connected to other perspectives than the singer's. This can be seen in his translation of the Hymn to Aphrodite.

\section{Deictic centres in Oras's Hymn to Aphrodite}

Ancient narrative tradition requires that the singer remain in the background (even when occasionally the narrator's focalisation leaves some traces). Accordingly, between the initial and final verses of the hymn no direct references to the singer's deictic centre occur. ${ }^{42}$ In the narrator's text only such local and deictic adverbs can be found, which refer to places and times far away,

\footnotetext{
39 Although Oras stresses the address to rejected lover (Sappho) in his translation, the grammatical subject (reluctant lover) is not expressed by third person personal pronouns, perhaps because there was not enough place in the hendecasyllable.

40 Due to textual problems it is not easy to tell whether references in v. 2 and v. 7 in the Greek text are to second or third person. See Voigt $1971 \mathrm{ad}$ loc. In the case of the demonstratives, there is balance: in Greek two different demonstrative and a relative pronoun, in Estonian also two demonstratives and a relative pronoun (although not always in same places).

${ }^{41}$ In: Oras 1936. Four forms of first person pronoun against the three in Catullus, although Oras omits the first person pronoun in the beginning of Catullus' Ille mi. The three 'you's of Catullus are all translated in corresponding places. The demonstrative ille is once rendered with demonstrative, once with a third person pronoun.

42 Because of my focus on explicit reference by deictics, I am not taking into consideration

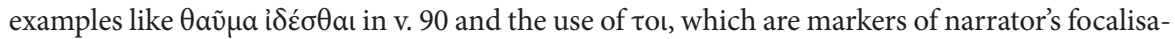
tion (as in de Jong 2004).
} 
local and time adverbs which point to the deictic centre are as a rule avoided. ${ }^{43}$ The character speech, in contrast, often uses local and time adverbs and first person pronouns, which refer to new deictic centres (Anchises or Aphrodite) and define their space, although pointing away from these centres occurs as well when needed by the story.

Verses 2-91 describe Aphrodite's power and her falling in love. She is the main actor, the deictics (mostly demonstrative, occasionally third person pronouns) refer to her or other characters. Shifts in time are marked by several

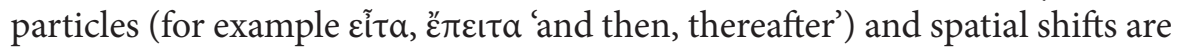
indicated by ع $\varepsilon v \theta \alpha$ 'there' (in verses 59, 60, 61, when Aphrodite starts to travel, in verse 80, where Anchises is described).

The translation of Oras is much less straightforward. He is retaining references to the secondary deictic centres of characters in his translation of speeches, but not always the same types of deictics and in the same places where these occur in the source text. ${ }^{44}$ For example, in Anchises' welcome address to the goddess several deictics in Greek text point to his perspective:

\begin{tabular}{|c|c|}
\hline 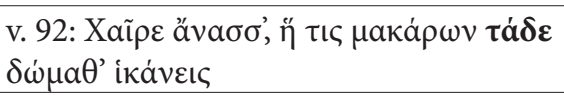 & $\begin{array}{l}\text { EW: Hail, lady, whoever of the blessed } \\
\text { (you) are that come to this house [here] }\end{array}$ \\
\hline $\begin{array}{l}\text { Oras, v. 78: Tervitan sind, ülev naine, } \\
\text { ükskõik mida õndsate tõugu }\end{array}$ & $\begin{array}{l}\text { I greet you, noble lady, whoever of the } \\
\text { family of the blessed }\end{array}$ \\
\hline 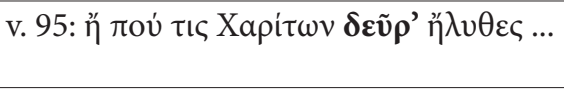 & $\begin{array}{l}\text { EW: Or, maybe, (you) are one of the } \\
\text { Graces come hither }\end{array}$ \\
\hline $\begin{array}{l}\text { Oras, v. 94-95: olgu sa ... // või ka } \\
\text { hariitidest üks }\end{array}$ & be you.... // or one of the Graces \\
\hline 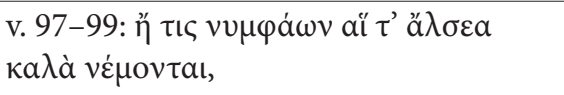 & $\begin{array}{l}\text { EW: or else one of the Nymphs who } \\
\text { haunt the pleasant woods, }\end{array}$ \\
\hline 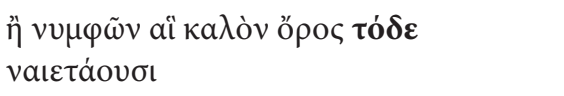 & $\begin{array}{l}\text { or of those who inhabit this lovely } \\
\text { mountain }\end{array}$ \\
\hline 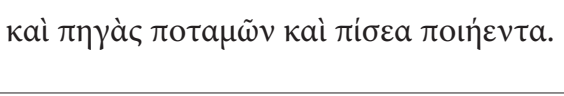 & $\begin{array}{l}\text { and the springs of rivers and grassy } \\
\text { meads. }\end{array}$ \\
\hline $\begin{array}{l}\text { Oras, v. } 82-83: \text {.... või nümf siit metsast } \\
\text { või kingult }\end{array}$ & $\begin{array}{l}\text { or a nymph from here (this) wood or } \\
\text { hill }\end{array}$ \\
\hline $\begin{array}{l}\text { või neilt allikailt üks, neilt lokkavailt } \\
\text { luhtavailt rohtmailt }\end{array}$ & $\begin{array}{l}\text { or one from these springs and from } \\
\text { these lushy grassy meadows. }\end{array}$ \\
\hline
\end{tabular}

43 Except tó $\tau \varepsilon$ 'then' in v. 54 (mentioning Anchises' living on Ida), which can indicate the narrator's focalisation.

44 In case of speeches, he usually translates the first and second person pronouns and even increases their number. 
In his translation of v. 92, Oras has omitted half of the verse and the deictics ( $\tau \alpha \dot{\delta} \delta \varepsilon$ 'these here') which accompany the nouns. However, he has used the compensatory method translators often recur to and inserted similar deictics into close-by verses, where Greek has none. Occasionally Oras becomes even more deictic than the Greek text, for example in Anchises speech where the mortal man expresses his wish to make love to Aphrodite:

\begin{tabular}{|c|c|}
\hline 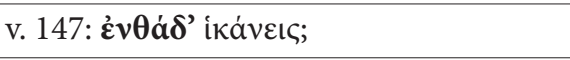 & you have come here $^{45}$ \\
\hline Oras, v. 127: Siia su juhtis Argosetapja & the Argos-slayer has led you here ${ }^{1}$ \\
\hline 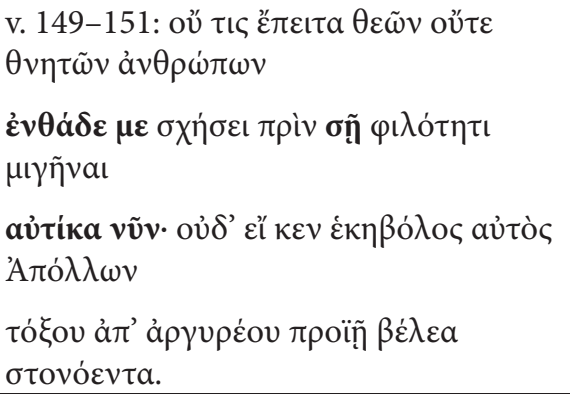 & $\begin{array}{l}\text { EW: then neither god nor mortal man } \\
\text { shall restrain me here till I have lain } \\
\text { with you in love right now, not even } \\
\text { if far-shooting Apollo himself should } \\
\text { launch grievous shafts, }\end{array}$ \\
\hline $\begin{array}{l}\text { Oras, v. 129-131: Ärgu siis tuldagi } \\
\text { häirima mind ei maalt ega taevast, }\end{array}$ & $\begin{array}{l}\text { Let then no-one from earth or heavens } \\
\text { come to disturb me, }\end{array}$ \\
\hline $\begin{array}{l}\text { Heidan Su kõrvale siin, jalamaid siin } \\
\text { süüvin su rüppe, }\end{array}$ & $\begin{array}{l}\text { (I) lay down besides you here, at once } \\
\text { here (I'll) enter your bosom, }\end{array}$ \\
\hline $\begin{array}{l}\text { rünnaku mind oma nooltega siis ise } \\
\text { Phoibos Apollon }\end{array}$ & $\begin{array}{l}\text { let Phoebus Apollon himself then attack } \\
\text { me with his shafts. }\end{array}$ \\
\hline
\end{tabular}

We can observe the presence of Greek text's 'here' and 'I' (v. 149-151) in the translation (verses 129 and 130) of Oras, although the temporal 'right now' has been translated by jalamaid ('at once'). Perhaps the synonym seemed to the translator more accurate for presenting the order of events (the love act has to start immediately) or more poetical, or more fitting into the verse after the penthemimeral caesura, where an anapaest-shaped space was available between two monosyllabic deictics (siin) and two second person pronouns $(s u)$. This verse (although exceptional in its high density of deictics) is typical for his character speeches, where deictic pronouns occur more frequently than in the Greek hymn.

45 The active has been replaced with the passive voice, thus bringing in another actor (Hermes, the Argos-slayer). 
These verses also offer a typical example of Oras's approach to monosyllabic deictic adverb siis. ${ }^{46}$ Both in Evelyn-White's English and Oras's Estonian translations of v. 149 the adverbs then and siis point away from the deictic centre and refer to the future, which in Greek is indicated by morphological future forms and the adverb हैं $\varepsilon \varepsilon \tau \alpha$ ('thereafter'). In Estonian the adverb is accompanied by impersonal and third person imperative forms in v. 129 and v. 131 (the translation of Greek verse 151, which uses the conditional). The adverb siis ('then') occurs a total of 18 times in Oras: in speeches it always refers to the events, which are going (or supposed or not supposed) to happen in the future from the character's point of view ( 9 occurrences); in narrator's text it indicates the next stage in the story-time ( 9 occurrences). Thus all these examples point away to the future.

The use of nüüd ('now') by Oras is, on the contrary, not coherent. In Greek text, $v \tilde{v} v$ is used straightforwardly as a temporal deictic. For example in Aphrodite's final speech (verses 247-254 in Homer, verses 175-179 in Oras), nü̈̈ refers to the present time of the character. ${ }^{47}$ But nüüd is also used for accompanying exhortations by Oras (v. 112, v. 121, 153 and an appeal in v. 161), where Greek uses other means (correspondingly verses 131, 141, 177 and 187). However, in the case of exhortations the speaker's point of view can still be felt, as for example in the one-word Estonian cohortative sentence Nü̈̈d!, meaning something like: 'I want you/us/me to do it NOW!'

Through the using of the adverb nü̈̈d, Oras the translator-narrator not only enlivens his story, but becomes present in it by referring to the narrator's temporal deictic centre. For example, Aphrodite's falling in love is introduced with the temporal adverb nüüd in v. 45:

\begin{tabular}{|c|c|}
\hline 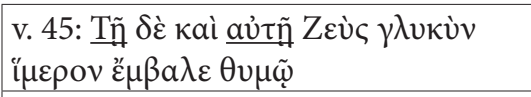 & $\begin{array}{l}\text { EW: But upon Aphrodite herself Zeus cast } \\
\text { sweet desire }\end{array}$ \\
\hline $\begin{array}{l}\text { Oras, v. 43: Kuid Kythereiatki nüïd, } \\
\text { teda ennastki Zeus pani äkki ihkama }\end{array}$ & $\begin{array}{l}\text { But now, Zeus, made suddenly Kythereia } \\
\text { herself desire. }\end{array}$ \\
\hline
\end{tabular}

The beginning of the story and the unexpectedness of the situation are underlined here by Oras with this insertion of a personal viewpoint and present time

\footnotetext{
46 Oras does not use it for translation of Greek тó $\varepsilon$ 'then', which occurs in v. 54 (but translates it with 'just', 'right now' in v. 46). Several temporal adverbials and pronouns, as toona, tollal ('that time') have not been used by Oras.

47 In Greek: v. 247: av̉ià $\varepsilon_{\mu} \mu o i ́$ ('but for me'), Oras: nü̈̈d, v. 252 vṽv ('now'), Oras: nü̈̈d, as opposed to $\pi \rho i$ ' 'before' in v. 249 (not translated by Oras).
} 
deictic centre. ${ }^{48}$ Oras-narrator appears again in the next stage of the story, when Aphrodite meets Anchises. Here we can see not only the 'now', but also the 'here':

\begin{tabular}{|c|c|}
\hline 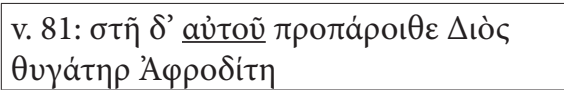 & $\begin{array}{l}\text { EW: And Aphrodite, the daughter of } \\
\text { Zeus stood before him. }\end{array}$ \\
\hline $\begin{array}{l}\text { Oras, v. } 68 \text { : Siin nagu neitsike-nooruke } \\
\text { nüïid end ilmutas Kypris }\end{array}$ & $\begin{array}{l}\text { Here like a young maiden }{ }^{49} \text { now Kypris } \\
\text { revealed herself. }\end{array}$ \\
\hline
\end{tabular}

The epiphany of the goddess is thus (like in lyric hymns) suddenly presented as felt by the narrator-poet, but only by the Estonian one who also shifts the attention from him (Anchises) to her (Aphrodite). This use of deictics also has a secondary, textual function, to underline the peak of this part of the narration, Aphrodite's arrival. This function becomes even clearer in the description of the love scene, where Oras-narrator starts to cumulate the adverbs:

\begin{tabular}{|c|c|}
\hline 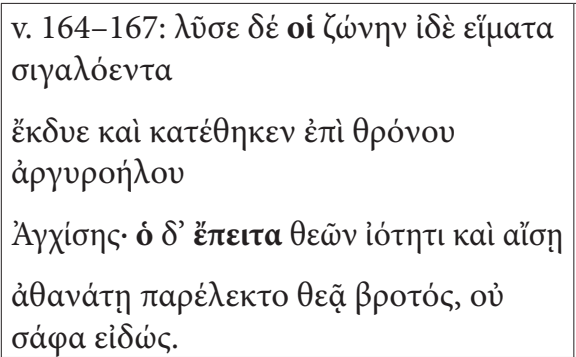 & $\begin{array}{l}\text { EW: and ... Anchises ... loosened her } \\
\text { girdle and stripped off (her) bright } \\
\text { garments and laid them down upon a } \\
\text { silver-studded seat. Then by the will of } \\
\text { the gods and destiny he lay with (her), } \\
\text { a mortal man with immortal goddess, } \\
\text { not clearly knowing what (he) did }\end{array}$ \\
\hline $\begin{array}{l}\text { Oras, v. 141-143: riisus siis ült särarüü, } \\
\text { avas vöö, hõbenaastusel istmel, } \\
\text { siis pani kokku nad kõik - ning taeva ja } \\
\text { saatuse tahtel } \\
\text { embaski põrmlane nüüd jumalannat - } \\
\text { ei mõistnud, mis juhtus. }\end{array}$ & $\begin{array}{l}\text { [Anchises] then robbed (stripped off) } \\
\text { (her) bright garments, loosened (her) } \\
\text { girdle and onto the silver-studded } \\
\text { seat then put (them) all together. And } \\
\text { according to the will of heaven and } \\
\text { destiny, the mortal man embraced now } \\
\text { the goddess - didn't understand what } \\
\text { happened. }\end{array}$ \\
\hline
\end{tabular}

In the Greek text only the peak of the scene, the beginning of the love act is

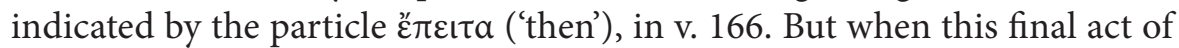
love is going to take place, the narrator Oras jumps again into the story, inserting his nü̈̈d ('now'). This use of the adverb nüüd ('now') by the narrator as a

\footnotetext{
48 It can also be interpreted as an insertion of the point of view of a character into the speech of the narrator (erlebte Rede or discours indirect libre).

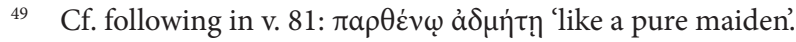


reference to a reached stage in the story, intertwined with a reference to the now-and-here of the moment occurs similarly twice more in his translation of speeches by Aphrodite. ${ }^{50}$

Thus it appears that differently from 'then', the 'now' has much more complex functions, as a direct make-believe temporal or textual deictic, indicating the new stage in the story. Knowing that for Oras, the role of deictics was important because of their possible role as anceps syllables in hexameter verse, we could seek correspondences between different prosodic weights of these words in verse (see Table 2) and their different deictic values. However, there is none: the local adverbs siin and sääl ('here' and 'there') always occur only in stressed long position, whereas sääl always points away from the speaker's point of view and siin can help to relive the past narration as being present. The temporal nüüd ('now') occurs also usually in the long position, but its usage is again quite incoherent, while siis ('then'), which is used quite coherently from deictic point of view (as discussed above), is prosodically used as an anceps.

Thus it appears that the choice of deictic adverbs and pronouns can only partly be explained with prosodic reasons (their use as anceps). In the case of the framing parts of the hymn the approach of Oras (reducing the number of deictics) seems to be consistent and following an interpretative approach of these poems as lyric hymns. In the case of narrative parts, the increase and variation of deictics and his use of the narrator's perspective during the third person narration seems to serve the goal of presenting the story in a lively and colourful way.

This interpretation will find support from a short analysis of actors in both texts, the Greek hymn and Oras's translation.

50 See Oras, v. 100 and v. 209. In corresponding Greek verses (v. 116, v. 289) the deictics do not

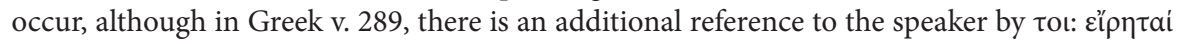

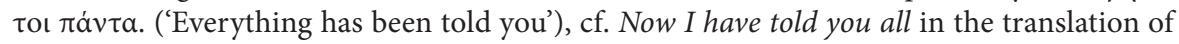
Evelyn-White and similar Nü̈̈d olen ütelnud kõik ('Now I've told all') by Oras. 
Table 2. Some temporal and local deictics and their positions

\begin{tabular}{|c|c|c|c|c|c|c|c|c|}
\hline & $\begin{array}{l}\text { siin 'here'/ } \\
\text { siit 'from } \\
\text { here' }\end{array}$ & $\begin{array}{l}\delta \varepsilon \tilde{v} \rho(o), \\
\text { other: } \\
\varepsilon \dot{\varepsilon} v \theta a ́ \delta \varepsilon \\
\text { 'here (to } \\
\text { this point)' }\end{array}$ & $\begin{array}{l}\text { nüüd } \\
\text { 'now', } \\
\text { other: } \\
\text { praegu } \\
\text { 'now' }\end{array}$ & $\begin{array}{l}v v(v), \\
v \tilde{v} v \\
\text { 'now' }\end{array}$ & $\begin{array}{l}\text { siis } \\
\text { 'then' }\end{array}$ & $\begin{array}{l}\text { Tó } \tau(\varepsilon) \\
\text { 'then' }\end{array}$ & $\begin{array}{l}\text { sääl } \\
\text { 'there'/ } \\
\text { säält } \\
\text { 'from } \\
\text { there' }\end{array}$ & $\begin{array}{l}\varepsilon \text { عैv } \theta(\alpha) \\
\text { 'hither' }\end{array}$ \\
\hline $\begin{array}{l}\text { short } \\
\text { position }\end{array}$ & 0 & - & 1 & - & 8 & 1 & 0 & - \\
\hline $\begin{array}{l}\text { long } \\
\text { position }\end{array}$ & $4+2$ & $1 / 1$ & 12 & 4 & 10 & - & $2+3$ & 1 \\
\hline $\begin{array}{l}\text { other } \\
\text { words }\end{array}$ & - & $1 / 2$ & 1 & - & - & - & - & 3 \\
\hline & \multicolumn{8}{|c|}{ other Greek words } \\
\hline & $\begin{array}{l}\eta ̋ \delta \varepsilon^{51} \\
\tau o ́ \delta \varepsilon \\
\text { 'this here' }\end{array}$ & 3 & & & & & 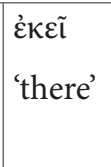 & 0 \\
\hline & \multicolumn{8}{|c|}{ adverbs, particles pointing to the shift in narration } \\
\hline & 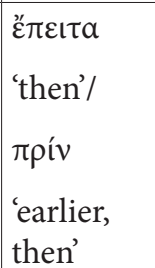 & $10 / 1^{52}$ & & & 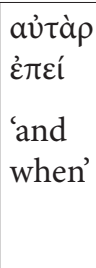 & 3 & & \\
\hline
\end{tabular}

\section{The multiplication of agents in the Hymn to Aphrodite}

Another feature of epic diction in this Homeric hymn is the focus on its main addressee, Aphrodite. The initial part of the Greek hymn (verses 1-42) celebrates Aphrodite's power, she is the actor, whose power is described through her deeds: she subdues everyone, except three virgin goddesses Athena, Artemis, and Hestia:

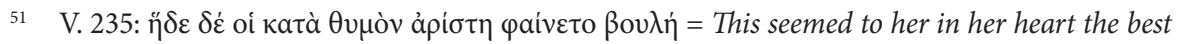
counsel (Evelyn-White). It would be interesting to know what Oras would have done with this example of secondary focalisation, but these verses belong to the part he omitted from his translation.

52 Only in v. 249 ( $\pi$ pì with infinitive in v. 150 can be excluded). 


\begin{tabular}{|c|c|}
\hline 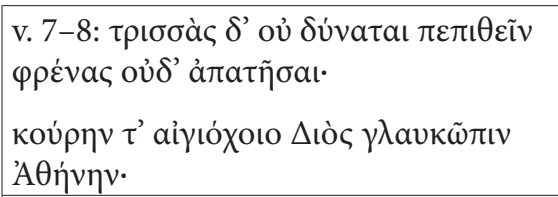 & $\begin{array}{l}\text { Yet (she) is unable to influence and de- } \\
\text { ceive three minds: } \\
\text { the daughter of aigis-bearing Zeus, } \\
\text { glimmering-eyed Athene. }\end{array}$ \\
\hline $\begin{array}{l}\text { Oras, v. } 7-8 \text { : Kolm aga on, kel meelt ei } \\
\text { ta pael ei ta püünised püüa: } \\
\text { aigise valduri tütar on üks neist, helk- } \\
\text { silm Athene }\end{array}$ & $\begin{array}{l}\text { Three are (these), whose mind neither } \\
\text { her slings nor her snares can capture, } \\
\text { one of them is the daughter of aigis- } \\
\text { bearer, bright-eyed Athene. }\end{array}$ \\
\hline
\end{tabular}

While the Greek text presents a quite straightforward narration - Aphrodite is unable to deceive the minds of three goddesses - Oras accumulates different actors. At first, he creates a complex phrase with numeral three as a subject in the main clause: three are (those). In the relative clause he introduces other new actors: in the place of Aphrodite, whose powers are insufficient, the subduers are her slings and her snares. The next, formulaic name and epithet verse refer-

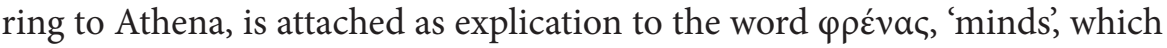
occurred in the preceding verse, in accordance with epic appositive style. However, Oras stresses once more that Athena is part of the trio, introducing her as the new grammatical subject. ${ }^{53}$ Instead of a focus on one goddess, who is described in a hymnal style, we see four new actors: the triad, the slings, the snares, and the daughter of Aegis-bearer.

The multiplication of actors (accompanied by nominalisation) continues in a similar manner. When Aphrodite has fallen in love with Anchises, she goes to Troy and takes the way through the clouds:

\begin{tabular}{|c|c|}
\hline 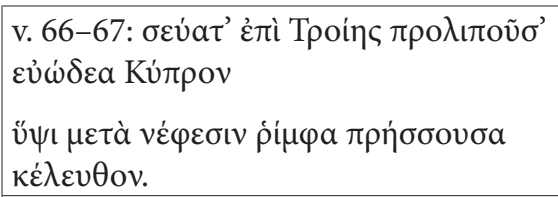 & $\begin{array}{l}\text { EW: (she) left sweet-smelling Cyprus } \\
\text { and went in haste towards Troy, } \\
\text { swiftly travelling high up among the } \\
\text { clouds }\end{array}$ \\
\hline $\begin{array}{l}\text { Oras, v. 55-56: Troojasse suundus ta } \\
\text { tuuline tee, imekiirelt ja kergelt lend } \\
\text { läbis pilvede vöö. }\end{array}$ & $\begin{array}{l}\text { To Troy went her windy path, won- } \\
\text { drously easily and swiftly flight pene- } \\
\text { trated the belt of clouds. }\end{array}$ \\
\hline
\end{tabular}

53 Cf. Evelyn-White: Yet there are three hearts that she cannot bend nor yet ensnare. First is the daughter of Zeus who holds the aegis, bright-eyed Athena. Oras changes the voice very often, Greek passive can become active and Greek active can become impersonal in his translation (Estonian does not have morphological passive voice), whereas the grammatical objects more often become the subjects in his translation than the other way round. 
Oras draws a different picture, where new actors enter: it is Aphrodite's windy way (tuuline tee) which goes to Troy, and her flight (lend), which passes through the belt (vöö) of clouds. Later in verses 70-72 the Greek narrator presents a short catalogue of numerous wild animals who come to greet the goddess, while in Estonian it is a pack of wolves, a crowd of lynches and a swarm of leopards (Oras, v. 58-60). In the end of the hymn, Aphrodite announces that she is pregnant and describes her feelings: ${ }^{54}$

\begin{tabular}{|c|c|}
\hline 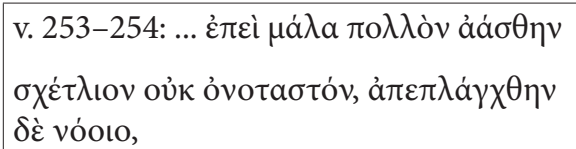 & $\begin{array}{l}\text { for (I) had become very mad, } \\
\text { miserably, without repair, and went } \\
\text { astray of mind. }\end{array}$ \\
\hline $\begin{array}{l}\text { Oras, v. 180-181: liig suur oli hullus, } \\
\text { meeletu, pöörane kihm, mis viis minult } \\
\text { taibu }\end{array}$ & $\begin{array}{l}\text { too great was the madness, mindless, } \\
\text { crazy desire, which took my wit. }\end{array}$ \\
\hline
\end{tabular}

The Aphrodite of the Estonian translation does not become mad straightforwardly, but the stress is on her folly's greatness and her mind and desires which take power; thus the goddess becomes a toy in the hands of different actors.

In Oras's translation, the personification is connected to nominalisation and abstraction: different groups (three, pack) and personified impersonalia (flight, mind, desires) who move her around. If we compare the Greek text and Oras's translation, we see that the number of acting personae (grammatical subjects) is much greater in Estonian. It can partly be the result of syntactic changes which arise from the differences of two languages (replacing passive constructions with the active or using personal verb forms in the place of infinitive and participle clauses), but in summary it is not the difference of syntax, but the translator's view of the world of Homeric hymns. Oras is describing this world with much greater vividness and as much more colourful and active than it seems to be in Greek.

\section{Conclusions}

It appears that it is characteristic of Oras's translation of Homeric hymns to omit or reduce these references to the deictic centre which are connected to the singer and the performance situation. By omitting the traditional formulas

\footnotetext{
54 Cf.: For very great has been my madness, my miserable and dreadful madness, and I went astray of my mind (Evelyn-White).
} 
which refer to the poet and his intention to continue the song (in the ends of hymns to Aphrodite and Pan), he re-interprets these poems as hymnal compositions, not epic prooemia. However, he conforms to the tradition by keeping the initial addresses to the Muses which point weakly to the deictic centre.

In his hymn to Apollo, Oras omits the initial auto-reference to the poet completely, also changing the grammatical subject and shifting the focus in the beginning from the singer to Apollo. The mythical story about the singer has been retained in the end, but with a strengthened addresses to the god and weakened references to the singer.

This omission of deictics only characterises his recreation of the performance situation. In character speeches his usage is close to lyric poetry with clear references to the deictic centres of the speakers. In the narrator's part, Oras does not follow the norms of epic narrative, where the perspectives of the narrator and the characters are clearly distinguishable. Instead, he occasionally introduces the poet's perspective and increases the numbers of acting subjects, which is supported by his insertion of the poet's perspective. In this way, the picture becomes much more diverse and lively, and the narration which is set in the past, becomes actualised in the present (of the narrator, but also of the reader). In this way an ancient singer whose position is important as a giver of praise and glory yields to a modern translator, who is becoming more invisible in his role of story-teller, but who reveals his presence even more during emotional moments. ${ }^{55}$

\footnotetext{
55 I thank Anne Lange, Sirje Olesk and Maria-Kristiina Lotman for their advice and invitation 5 years ago to the seminar dedicated to Ants Oras, which gave me the impulse to formulate and prepare for publication the results of several different analyses. The article has been written with the support of the Estonian Research Council grant PUT 132. I am grateful to Raili Marling for the revision of my English. The approach to the study of deixis through contrastive analysis of texts and their translations is partly a result of the training which every student of ancient Greek received in the classes of Jaan Unt (1947-2012, lecturer of ancient literature and Greek at the University of Tartu, scholar and translator of ancient literature), where text analysis and interpretation were combined with the discussion of translation principles and possibilities; partly of seminars devoted to deixis at the university's Department of French; see Monticelli, Pajusalu, Treikelder (eds.) 2005. This led to a series of student papers in the Department of Classics, quoted above (note 9).
} 


\section{References}

Allen, Thomas W.; Sikes, Edward E. (eds.) 1904. The Homeric Hymns. Edited, with preface, apparatus criticus, notes, and appendices. London: Macmillan. URL: http://www.perseus.tufts.edu/hopper/text?doc=Perseus\%3Atext\%3A1999.04.00 29\%3Atext\%3Dcomm\%3Apoem\%3D3\%3Acommline\%3D169

Antiigiveeb = Ivo Volt (ed.), Antiigiveeb. URL: http://www.fl.ut.ee/et/380160_(accessed September 15, 2015).

Aunin, Tiina; Lange, Anne (eds.) 2008. Widening circles: the critical heritage of Ants Oras. Tallinn: Tallinn University Press.

Baikov, Krista 2008. Osutussõnad ja nende tõlkimine Hesiodose "Tööde ja päevade" värssides 293-596. Seminaritöö. Tartu [unpublished seminar paper in the seminar library of Classical Philology, University of Tartu; pdf in the possession of the author].

Bakker, Egbert J. Poetry in Speech. Orality and Homeric Discourse. Ithaca and London: Cornell University Press.

Brunet, Philippe (ed.) 2014. Traditions du patrimoine antique - "Homère en hexamètres" - Rencontre internationale de traducteurs, Paris, 26 mars 2012 Réfectoire des Cordeliers, 7e édition des Dionysies. (Anabases 20). URL: https:// anabases.revues.org/4768.

Bühler, Karl 1990. Theory of Language. Amsterdam \& Philadelphia: John Benjamins.

Calame, Claude 1986. Le récit en Grèce Ancienne. Enonciations et représentations de poètes. Paris: Méridiens-Klincksieck.

Calame, Claude 2004. Deictic ambiguity and auto-referentiality: some examples from Greek poetics. In: Arethusa 37(3): 415-443.

Calame, Claude 2005. Masques d’autorité. Fiction et pragmatique dans la poétique grecque antique. Paris: Les Belles Lettres.

Campbell, David A. (trans.) 1994. Greek Lyric I. Sappho and Alcaeus. (Loeb Classical Library 142). Cambridge, Mass.: Harvard University Press; London: William Heinemann.

Clay, Jenny S. 2006. The Politics of Olympus. Form and meaning in the major Homeric Hymns. Second edition. Bristol Classical Press.

Clay, Jenny S. 2011. The Homeric Hymns as Genre. In: Faulkner, Andrew (ed.), The Homeric Hymns. Interpretative Essay. Oxford: University Press, 232-251. 
Detienne, Marcel 1990. Les maîtres de vérité dans la Grèce archaïque. Paris: Éditions La Découverte.

Devine, Andrew Mackay; Stephens, Laurence D. 1994. The Prosody of Greek Speech. New York and Oxford: Oxford University Press.

Dickey, Eleanor 2003. Greek Forms of Address. From Herodotus to Lucian. Oxford: Clarendon Press.

Dik, Helma Marietta Josine 1995. Word Order in Ancient Greek: A Pragmatic Account of Word Order in Herodotus. Amsterdam: J.C. Gieben.

EAB 2014 = Päll, Janika; Volt, Ivo; Näripä, Neeme; Kurs, Kristin (eds.) 2014. Eesti antiigitõlke bibliograafia (EAB). Versioon 1.0, 2014. 1-16. Võrguteavik. URL: http://philologic.ut.ee/EAB_1.0_2014.pdf (accessed September 15, 2015).

Eesti Värss 2004 = Lotman, Mihhail; Lotman, Maria-Kristiina; Sütiste, Elin (eds.) 2004. Eesti Värss. URL: http://www.ut.ee/verse (accessed September 15, 2015).

Evelyn-White, Hugh G. 1914. Homeric Hymns. (Loeb Classical Library 57). Cambridge, Mass.: Harvard University Press; London: William Heinemann. [Quoted from http://www.perseus.tufts.edu/]

Felson, Nancy (ed.) 2004. The Poetics of Deixis in Alcman, Pindar, and other Lyric. (Arethusa 37(3)).

Fowler, Robert Louis 1987. The Nature of Early Greek Lyric: Three Preliminary Studies. Toronto: University of Toronto Press.

Fränkel, Hermann 1955. Eine Stileigenheit der frühgriechischen Literatur. In his: Wege und Formen frühgriechischen Denkens. Literarische und philosophiegeschichtliche Studien, ed. by Tietze, Franz. München: C.H. Beck, 40-96.

Gerber, Douglas E. (ed.) 1997. A Companion to the Greek Lyric Poets. Leiden: Brill.

Groningen, Bernhard Abraham van 1958. La composition littéraire archaïque grecque. Amsterdam: Amsterdam: Noord-Hollandsche Uitg.

Homeros 1960. Ilias. Tallinn: Eesti Riiklik Kirjastus (Estonian translation by August Annist and Karl Reitav).

Homeros 1963. Odüsseia. Tallinn: Eesti Riiklik Kirjastus (Estonian translation by August Annist and Karl Reitav).

de Jong, Irene; Nünlist, René; Bowie, Angus (eds.) 2004. Narrators, Narratees, and Narratives in Ancient Greek Literature. Studies in Ancient Greek Narrative 1. Leiden, Boston: Brill. 
de Jong, Irene 2004. Narrators and Focalizers: the Presentation of the Story in the Iliad. London: Bristol Classical Press.

Kaalep, Ain; Torpats, Ülo (eds.) 1971. Rooma kirjanduse antoloogia. Tallinn: Eesti Raamat.

Kärtna, Lis-Ann 2010. Osutussõnade tõlkimine Platoni "Pidusöögis" St. III p. 172 a1 186 e1. Bakalaureusetöö. Tartu [unpublished seminar paper in the seminar library of Classical Philology, University of Tartu; pdf in the possession of the author].

Kirk, Geoffrey Stephen 1989. The epic tradition after Homer and Hesiod. In: Easterling, Patricia Elizabeth; Knox, Bernard M.W. (eds.), The Cambridge History of Classical Literature, Volume I Part I. Early Greek Poetry. Cambridge: Cambridge University Press, 65-75.

Kiss, Kadi 2010. Osutussõnade tõlkimine Vergiliuse "Aeneises" 1. laulus värssides 1-350. Bakalaureusetöö. Tartu [unpublished seminar paper in the seminar library of Classical Philology, University of Tartu; pdf in the possession of the author].

Lange, Anne 2004. Ants Oras. Tartu: Ilmamaa.

Lange, Anne 2007. The poetics of translation of Ants Oras. Doktoritöö. Tallinn: Tallinna Ülikooli Kirjastus. URL: http://e-ait.tlulib.ee/115/

Latacz, Joachim 1994. Erschliessung der Antike. Kleine Schriften zur Literatur der Griechen und Römer. Stuttgart, Leipzig: Teubner = Latacz, Joachim 1985. Realität

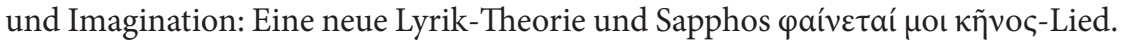
In: Museum Helveticum 42: 67-94.

Latacz, Joachim 2000. Homers Ilias: Gesamtkommentar. Prolegomena. MünchenLeipzig: Saur.

Lefkowitz, Mary R. 1963. The First Person in Pindar. In: Harvard Studies in Philology 67: 177-253.

Lefkowitz, Mary R. 1991. First-Person Fictions. Pindar's Poetic “I”. Oxford: Clarendon Press.

Leitsch, Vincent B. 2008. Widening Circles: The Postwar Critical Work of Ants Oras. In: Aunin, Tiina; Lange, Anne (eds.), Widening circles: the critical heritage of Ants Oras. Tallinn: Tallinn University Press, 15-32.

Lotman, Maria-Kristiina 2012. Equimetrical Verse translation in Estonian Poetic Culture. In: Chalvin, A.; Lange, A.; Monticelli, D. eds. Between Cultures and Texts. Itineraries in Translation History. Frankfurt am Main: Peter Lang Verlag, 137-150. 
Mägiste, Julius 1976. Ants Orase “Aeneise-tõlke” keelelise kujunduse puhul. In: Tulimuld 1: 35-41.

Monticelli, Daniele; Pajusalu, Renate; Treikelder, Anu (eds.) 2005. De l'énoncé à l'énonciation et vice-versa. Regards multidisciplinaires sur la deixis = Lausungist lausumiseni ja vastupidi. Multidistsiplinaarsed vaated deiksisele = From utterance to uttering and vice versa. Multidisciplinary views on deixis. 1-2. Tartu: Tartu Ülikooli Kirjastus.

Murdvee, Mari 2006. Homerose hümn Deelose Apollonile. In: Päll, Janika (ed.), Vanakreeka kirjanduse antoloogia. Tallinn: Varrak, 71-76.

Norden, Eduard 1913. Agnostos Theos. Berlin: B.G. Teubner.

Nünlist, René 2004. The Homeric Hymns. In: de Jong, Irene; Nünlist, René; Bowie, Angus (eds.), Narrators, Narratees, and Narratives in Ancient Greek Literature. Studies in Ancient Greek Narrative 1, 35-41.

Olesk, Sirje (ed.) 1997. AKADEEMIA kirjades. Ants Orase ja Ivar Ivaski kirjavahetus 1957-1981. Tartu: Eesti Kirjandusmuuseum.

Oras, Ants (trans.) 1936. Catullus, Carmina. In: Looming 9: 1013-1016.

Oras, Ants 1938. On some aspects of Shelley's poetic imagery. In: Acta et Commentationes Universitatis Tartuensis (Dorpatensis), B, Humaniora. XLIII, 4. Tartu: Mattiesen, 1-71.

Oras, Ants 1962. Vergilius ja eesti heksameetri probleem. In: Tulimuld 4: 242-248.

Oras, Ants (trans.) 1976. Homeros. Hümn Aphroditele. In: Tulimuld 1: 29-35.

Oras, Ants (trans.) 1977a. Homerose hümn Apollonile. In: Tulimuld 1: 24-28.

Oras, Ants (trans.) 1977b. Homeros. Hümn Paanile. In: Tulimuld 2: 90-91.

Oras, Ants (trans.) 1977c. Sappho I, II. In: Tulimuld 3: 142.

Pajusalu, Renate 1999. Deiktikud Eesti keeles. Tartu: TÜ Kirjastus. URL: http://www. folklore.ee/seminar/deiktikud/

Päll, Janika 2005. Deixis and word order in Greek lyric poetry. In: Monticelli, Daniele; Pajusalu, Renate; Treikelder, Anu (eds.), De l'énoncé à l'énonciation et vice-versa. Regards multidisciplinaires sur la deixis = Lausungist lausumiseni ja vastupidi. Multidistsiplinaarsed vaated deiksisele $=$ From utterance to uttering and vice versa. Multidisciplinary views on deixis. 1-2, 329-345.

Päll, Janika 2007. Translating ancient Greek aspect: Sappho's Fr.1 Voigt (To Aphrodite). Monticelli, Daniele; Treikelder, Anu (eds.), Studia Romanica Tartuensia 6: 43-65. 
Päll, Janika 2014. La traduction d'Homère en Estonie: une bataille pour ou contre l'hexamètre quantitatif. In: Anabases 20: 211-234.

Parvits, Triin 2010. Deiksise kasutamine Platoni “Pidusöögis” Stephanuse lehekülgedel 186e 1 - 201c 3. Bakalaureusetöö. Tartu [unpublished seminar paper in the seminar library of Classical Philology, University of Tartu; pdf in the possession of the author].

Pille, Katri 2008. Osutussõnad ja nende tõlkimine Hesiodose “Tööde ja päevade" värssides 597-828. Seminaritöö. Tartu [unpublished seminar paper in the seminar library of Classical Philology, University of Tartu; pdf in the possession of the author].

Rootsma, Ruth 2011. Deiksis ja selle tõlkimine Euripidese Bakhantides (värsid 1-214). Tartu [unpublished seminar paper in the seminar library of Classical Philology, University of Tartu; pdf in the possession of the author].

Steinrück, Martin 1992. Rede und Kontext. Zum Verhältnis von Person und Erzähler in frühgriechischen Texten. Bonn: Habelt.

Tuulmets, Kristen 2008. Osutavad sõnad Hesiodose “Töödes ja päevades”, värsid 1-292. Seminaritöö. Tartu [unpublished seminar paper in the seminar library of Classical Philology, University of Tartu; pdf in the possession of the author].

Tzamali, Eleni 1996. Syntax und Stil bei Sappho. Dettelbach: J.H. Röll.

Unt, Jaan 1992. Saatesõna. In: Vergilius. Bucolica. Aeneis, Tallinn: Hortus Litterarum, 314-325.

Vergilius 1992. Bucolica. Aeneis. Tõlkinud Ants Oras. Tallinn: Hortus Litterarum.

Voigt, Eva-Maria (ed.) 1971. Sappho et Alcaeus. Fragmenta. Amsterdam: Athenaeum Polak \& Van Gennep. 